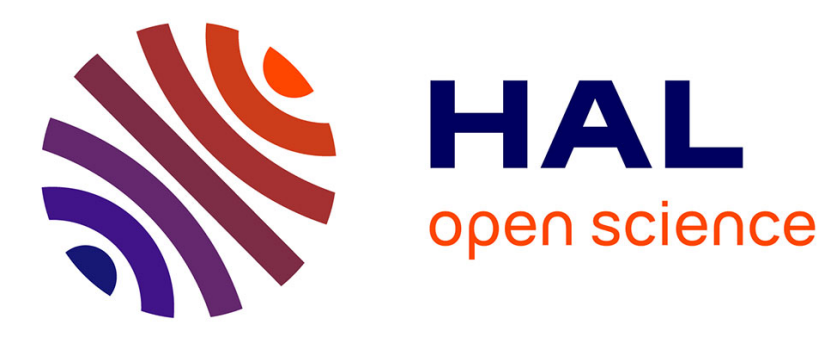

\title{
Development of a novel flow sensor for copper trace analysis by electrochemical reduction of 4-methoxybenzene diazonium salt
}

Bogdan Feier, Didier Floner, Cecilia Cristea, Robert Sandulescu, Florence

Geneste

\section{To cite this version:}

Bogdan Feier, Didier Floner, Cecilia Cristea, Robert Sandulescu, Florence Geneste. Development of a novel flow sensor for copper trace analysis by electrochemical reduction of 4-methoxybenzene diazonium salt. Electrochemistry Communications, 2013, 31, pp.13-15. 10.1016/j.elecom.2013.02.025 . hal-00844366

\section{HAL Id: hal-00844366 https://hal.science/hal-00844366}

Submitted on 10 Dec 2013

HAL is a multi-disciplinary open access archive for the deposit and dissemination of scientific research documents, whether they are published or not. The documents may come from teaching and research institutions in France or abroad, or from public or private research centers.
L'archive ouverte pluridisciplinaire $\mathbf{H A L}$, est destinée au dépôt et à la diffusion de documents scientifiques de niveau recherche, publiés ou non, émanant des établissements d'enseignement et de recherche français ou étrangers, des laboratoires publics ou privés. 
Development of a novel flow sensor for copper trace analysis by electrochemical reduction of 4-methoxybenzene diazonium salt

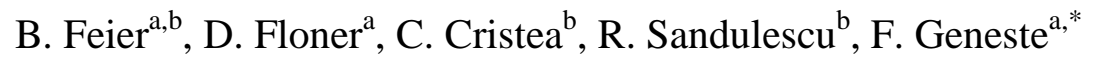

${ }^{\text {a }}$ University of Rennes 1, UMR-CNRS 6226, Institut des Sciences Chimiques de Rennes, Equipe MaCSE, Campus de Beaulieu, 35042 Rennes cedex, France

b "Iuliu Hatieganu” University of Medicine and Pharmacy, Faculty of Pharmacy, 4 Pasteur str, 400012 Cluj-Napoca, Romania

\begin{abstract}
Due to the rapidity and the effectiveness of the method, the reduction of diazonium salts has been widely used to functionalize electrodes for sensor applications. However, the resulting organic film usually designed to provide complexing capabilities for the species to be determined could affect the sensor properties. The electrochemical reduction of 4methoxybenzene diazonium salt on graphite felt that leads to the formation of an organic film with unexpected high affinity for copper ions is presented. This property combined with a flow electrochemical system led us to achieve a sensitive sensor for copper detection, with good selectivity towards some common interferent ions.
\end{abstract}

Keywords: sensor, graphite felt, diazonium salts, copper, flow

\title{
1. Introduction
}

The functionalization of surfaces by reduction of diazonium salts has known a growing interest due to the versatility and rapidity of the method, which leads to strong covalent bonds between a wide range of functionalized molecules and surfaces [1, 2]. As the mechanism involves the formation of highly reactive aryl radicals, multilayers are usually obtained by

\footnotetext{
* Corresponding author. Tel: +332232359 65. Fax: +332232359 67. E-mail address:

florence.geneste@univ-rennes1.fr (F. Geneste)
} 
reaction of the radicals on already-grafted aryl species [3]. The resulting organic layer brings new properties to the covering substrate, leading to applications in many areas such as corrosion [4], insulating material [5] and catalysis [6]. It has also been widely used in the fabrication of sensors and biosensors [7-9]. Since the reduction of diazonium salts is easily performed electrochemically, it has been fully exploited to prepare chemically modified electrodes (CMEs) for electroanalysis. A particularly interesting area in CMEs is the preconcentration of analytes at the electrode surface for trace analysis. Various CMEs with functional groups interacting specifically with heavy metals have been prepared to preconcentrate them at the electrode surface before their analysis by stripping voltammetry. In this specific area, only a few articles deal with electro-assisted methods [8-10]. Thus, covalent immobilization of oligopeptides by diazonium salt reduction on GC electrode has been reported for the detection of copper [9]. Comparison with the same peptide ligand immobilized by thiol links on gold led the authors to conclude that the performance of the sensor is dominated by the receptor rather than the grafting method.

However, an important issue is still the effect of the multilayer film on the response of the sensor. The reduction of 4-methoxybenzene diazonium salt (4-MeOBDS) on a graphite felt electrode leading to the formation of an organic film with high affinity for copper ions is presented. This property combined with a preconcentration performed in a flowing system allowed the achievement of a $\mathrm{Cu}^{2+}$ sensor with high sensitivity and good selectivity towards some common interfering ions.

\section{Experimental section}

The graphite felt (RVG 4000) was obtained from Mersen (France). All the chemicals were purchased from Acros or Aldrich. All solutions were prepared with ultrapure water (18.2 M $\Omega$, Millipore Simplicity). All glassware and flow reactor were rinsed with a $10 \% \mathrm{HNO}_{3}$ solution followed by ultrapure water before use to avoid metal contamination.

\subsection{Preparation of the modified electrodes}

1 eq. of $\mathrm{NaNO}_{2}$ was added to a solution of $100 \mathrm{mg}$ of $p$-anisidine or $p$-toluidine in $100 \mathrm{~mL}$ of degassed $0.5 \mathrm{M} \mathrm{HCl}\left(8 \times 10^{-3} \mathrm{~mol} \mathrm{~L}^{-1}\right)$ in a divided flow cell fitted with a graphite felt electrode (48 mm diameter, $6 \mathrm{~mm}$ thickness) located between two counter electrodes [6] at $0.2 \mathrm{~V}_{\mathrm{SCE}}$ for $10 \mathrm{~min}$ under nitrogen $\left(3 \mathrm{~mL} \cdot \mathrm{min}^{-1}\right)$. Then the derivatized graphite felt was ultrasonicated 4 times in deionized water for $15 \mathrm{~min}$. 


\subsection{Electrochemical analysis}

Copper ions were accumulated at the electrode $\left(0.5 \mathrm{~cm}^{3}\right)$ at open circuit potential by flowing an aqueous solution of copper(II) chloride (volume: $100 \mathrm{~mL}$ ) through the electrode in a flow reactor using a peristaltic pump (Minipuls 3, Gilson) at $20 \pm 1{ }^{\circ} \mathrm{C}$ (flow rate: $8 \mathrm{~mL} \mathrm{~min}^{-1}$ ) [10]. The electrode was then removed and transferred to a standard cell for LSSV (linear sweep stripping voltammetry) analysis in $0.5 \mathrm{M} \mathrm{NaBF}_{4}$ (selected conditions: reduction at $-0.5 \mathrm{~V}_{\mathrm{SCE}}$ for $5 \mathrm{~min}$ and then the potential was varied from -0.5 to $0.8 \mathrm{~V}_{\mathrm{SCE}}$ ). These experiments were carried out using a VersaSTAT3 AMETEK Model (Princeton Applied Research) potentiostat/galvanostat with a platinum sheet auxiliary electrode, a saturated calomel reference electrode and the graphite felt sample $\left(0.5 \mathrm{~cm}^{3}\right)$ fixed to a platinum wire. Scan rate: $0.1 \mathrm{~V} \mathrm{~s}^{-1}$

\subsection{Real sample analysis}

An oral solution containing copper (Oligosol from Labcatal) was used for these experiments. Using the declared concentration in copper $\left(725.2 \mu \mathrm{g} \mathrm{Cu}^{2+} / 2 \mathrm{~mL}\right.$ oral solution), a solution of 5 $\times 10^{-8}$ of copper in ultrapure water was prepared by diluting the Oligosol solution. It was analyzed by the procedure described above, giving rise to an electrochemical signal due to the presence of copper in the Oligosol solution. The concentration of copper was then determined by the standard addition method $(n=3)$.

\section{Results and discussion}

The derivatization of the graphite felt was achieved by electrochemical reduction of 4MeOBDS prepared in situ at $-0.2 \mathrm{~V}_{\mathrm{SCE}}$ in $0.5 \mathrm{M} \mathrm{HCl}$ for $10 \mathrm{~min}$ in a flow cell. 4Methylbenzene diazonium salt (4-MeBDS) was grafted in the same conditions for comparison. The passivation of the graphite fibers modified with aryldiazonium salts was investigated by cyclic voltammetry using potassium ferricyanide as a redox probe. Fig. 1A shows a cyclic voltammogram of potassium ferricyanide before and after modification with the aryldiazonium salts.

Figure 1 
After the modification of the surface, a blocking effect was observed with a significant decrease of the redox peaks of ferricyanide, attesting the presence of a molecular layer on the graphite fibers.

The electrode modified with 4-MeOBDS was used for copper detection. The analytical method was performed in two steps. The preconcentration of copper on the modified electrode was first carried out in a flow reactor at open circuit. Then, the felt was transferred in a standard three-electrode cell and analyzed by linear sweep stripping voltammetry (LSSV) in a $0.5 \mathrm{M}$ aqueous solution of $\mathrm{NaBF}_{4}$. Trapped $\mathrm{Cu}^{2+}$ ions were first reduced and then the potential was shifted in anodic direction, leading to the apparition of a well-defined peak at $0.06 \mathrm{~V}_{\mathrm{SCE}}$ (Fig. 1B).

The analytical conditions were studied. The highest electrochemical signal was obtained with a deposition potential of $-0.5 \mathrm{~V}_{\mathrm{SCE}}$ (Fig. 2A).

Figure 2

Reduction at more cathodic potentials led to lower electrochemical responses, due to the competition with water reduction. Different times for the reduction step were also tested (Fig. 2B). After $5 \mathrm{~min}$, the electrochemical signal seems to reach a plateau, corresponding to the total reduction of copper trapped into the electrode. These analytical conditions (reduction at $-0.5 \mathrm{~V}_{\mathrm{SCE}}$ for $5 \mathrm{~min}$ ) were then used in the following experiments.

The preconcentration step was then investigated. The flow rate did not influence the electrochemical signal at $>8 \mathrm{~mL} \mathrm{~min}^{-1}$ (Fig. 2C). This value was kept in the following experiments. The complexation on the graphite felt electrode was then performed with different volumes of a $10^{-7} \mathrm{M}$ copper solution at $8 \mathrm{~mL} \mathrm{~min}^{-1}$ (Fig. 2D). The electrochemical signal increased with the volume of the copper solution percolated through the electrode, without reaching a plateau. In order to shorten the analysis time, the equilibrium was not reached and a volume of $100 \mathrm{~mL}$ was used.

The preconcentration step was then performed, according to these conditions, with a volume of $100 \mathrm{~mL}$ at $8 \mathrm{~mL} \mathrm{~min}{ }^{-1}$ in the following experiments, giving rise to a total analysis time of $18 \mathrm{~min}$. It is noteworthy that it was not necessary to wash the graphite sample between the preconcentration of $\mathrm{Cu}^{2+}$ on the electrode and the LSSV analysis for concentrations lower than $5 \times 10^{-7} \mathrm{~mol} \mathrm{~L}^{-1}$, since no electrochemical signal was observed by LSSV analysis in a three electrode cell for copper concentrations lower than $5 \times 10^{-7} \mathrm{~mol} \mathrm{~L}^{-1}$. 
The same analysis was performed with the felt modified by 4-MeBDS. Interestingly, the electrochemical signal corresponding to the stripping of copper (Fig. 1B) was not observed, underlying the accumulation properties of the methoxyaryl film.

The dependence of the copper signal on the concentration of the analyzed solution is given in Fig. 3A.

Figure 3

The curve is nonlinear as expected for an accumulation step by complexation [11]. The plateau corresponding to the maximum of copper loading in the electrode was not reached in this range of concentrations. Solutions with higher concentrations of copper were not investigated to avoid problems linked to the introduction of a supplementary washing step. The highest value obtained for the electric charge corresponds to a volume concentration of copper around $6 \times 10^{-10} \mathrm{~mol} \mathrm{~cm}^{-3}$. This value is 10 to 100 times lower than volume concentrations usually obtained with modified graphite felt electrodes $[6,10]$, suggesting that the maximum of coverage is not reached and that species responsible for the accumulation of copper ions are in small amount in the organic film. The lowest concentration giving rise to a measurable signal was $5 \times 10^{-9} \mathrm{~mol} \mathrm{~L}^{-1}$.

The value is much below the European drinking water guidelines for copper set at $1.6 \times 10^{-5}$ mol $\mathrm{L}^{-1}$. It is also in the same order as values given recently in literature such as $10^{-9} \mathrm{~mol} \mathrm{~L}^{-1}$ for a cyclam-functionalized silica-modified electrode [12] and $5 \times 10^{-9} \mathrm{~mol} \mathrm{~L}^{-1}$ for a poly(pyrrole-malonic acid) film modified carbon electrode [13] with accumulation times between 10 and $30 \mathrm{~min}$.

The selectivity of the porous sensor for $\mathrm{Cu}^{2+}$ was investigated in the presence of some common metal ion interferents $\mathrm{Pb}^{2+}, \mathrm{Fe}^{2+}, \mathrm{Cd}^{2+}, \mathrm{Ni}^{2+}, \mathrm{Zn}^{2+}$ and $\mathrm{Co}^{2+}$ in the same concentration. A solution of $\mathrm{Cu}^{2+}\left(10^{-7} \mathrm{~mol} \mathrm{~L}^{-1}\right)$ and interferent ion $\left(10^{-7} \mathrm{~mol} \mathrm{~L}^{-1}\right)$ was percolated through the porous electrode. The electric charge measured for each experiment is given in Fig. 3B. The electrochemical signal is almost constant for $\mathrm{Fe}^{2+}, \mathrm{Zn}^{2+}$ and $\mathrm{Ni}^{2+}$, and a slight decrease was observed for $\mathrm{Pb}^{2+}, \mathrm{Co}^{2+}$ and $\mathrm{Cd}^{2+}$.

In order to evaluate the performance of the novel flow sensor, the determination of $\mathrm{Cu}^{2+}$ was carried out in a food supplement containing copper $\left(5.7 \times 10^{-3} \mathrm{~mol} \mathrm{~L}^{-1}\right)$. The concentration value of $\mathrm{Cu}^{2+}$ determined by the standard addition method, was $5.5 \pm 0.9 \times 10^{-3} \mathrm{~mol} \mathrm{~L}^{-1}$, suggesting that the analytical method can be used for the analysis of $\mathrm{Cu}^{2+}$ in real samples. 
Since the methoxy group does not have good coordination properties for $\mathrm{Cu}^{2+}$, it is unlikely that the accumulation of copper in the film would be only due to the complexation of $\mathrm{Cu}^{2+}$ on $\mathrm{MeO}$ groups. The presence of azo species $(-\mathrm{N}=\mathrm{N}-)$, resulting from the chemical reaction between diazonium ions and already grafted methoxyphenyl groups [14] could help the complexation of copper ions in the film. Since electrodes modified with 4-MeBDS did not show any complexation properties, the methoxy group could either help the coordination of copper, or turn the deposition properties of the film and influence the amount of azo groups.

\section{Conclusion}

Reduction of 4-MeOBDS on graphite electrodes led to the formation of an organic film with high affinity for copper ions. This interesting property led us to achieve a sensitive flow sensor based on this modified electrode. The derivatization of the electrode is easy and the sensor does not require long-time preparation. The nature of the para substituent on the phenyl ring could influence the mechanism of film deposition and the formation of azo groups, which could be at the origin of the accumulation properties of the organic film. If the reduction of diazonium salts is a very interesting method to functionalize electrodes, it is worth noting that the resulting film can have intrinsic properties, due to the presence of azo groups inside the film.

\section{Acknowledgements}

We are grateful for the financial support to "Iuliu Hatieganu" University of Medicine and Pharmacy (project POS-DRU 88/1.5/S/56949), to Agence Universitaire de la Francophonie (project CE/MC/288/10) and to Ecole Doctorale SDLM.

\section{References}

[1] J. Pinson, F. Podvorica, Chem. Soc. Rev. 34 (2005) 429.

[2] M. M. Chehimi, Aryl Diazonium Salts, Wiley-VCH, Weinheim, 2012.

[3] J. K. Kariuki, M. T. McDermott, Langmuir 17 (2001) 5947.

[4] C. Combellas, M. Delamar, F. Kanoufi, J. Pinson, F. I. Podvorica, Chem. Mater. 17 (2005) 3968.

[5] X. Lefèvre, O. Segut, P. Jergou, S. Palacin, B. Jousselme, Chem. Sci. 3 (2012) 1662.

[6] R. Marion, G. Muthusamy, F. Geneste, J. Catal. 286 (2012) 266. 
[7] D.-J. Chunga, S.-H. Ohb, S. Komathic, A. I. Gopalanc, K.-P. Leec, S.-H. Choi, Electrochim. Acta 76 (2012) 394.

[8] S. Betelu, C. Vautrin-U1, A. Chaussé, Electrochem. Commun. 11 (2009) 383.

[9] G. Liu, T. Böcking, J. J. Gooding, J. Electroanal. Chem. 600 (2007) 335.

[10] R. Nasraoui, D. Floner, F. Geneste, Electrochem. Commun. 12 (2010) 98.

[11] G. Liu, Q. T. Nguyen, E. Chow, T. Bocking, D. B. Hibbert, J. J. Gooding, Electroanalysis 18 (2006) 1141.

[12] S. Goubert-Renaudin, M. Etienne, Y. Rousselin, F. Denat, B. Lebeau, A. Walcarius, Electroanalysis 21 (2009) 280.

[13] E. Pereira, B. L. Rivas, M. Heitzman, J.-C. Moutet, C. Bucher, G. Royal, E. Saint Aman, Macromol. Symp. 304 (2011) 115.

[14] F. Le Floch, M. Matheron, F. Vinet, J. Electroanal. Chem. 660 (2011) 127.

\section{Figure captions}

Figure 1: A) Cyclic voltammograms at graphite felt electrode of $\mathrm{K}_{3}\left[\mathrm{Fe}(\mathrm{CN})_{6}\right]$ in $0.5 \mathrm{M}$ phosphate buffer $\mathrm{pH}=7$ before ( - ) and after grafting of 4-MeOBDS (----) and 4-MeBDS (....) B) Voltammogram obtained by LSSV (-0.5 V for $5 \mathrm{~min}$ ), of trapped copper (100 $\mathrm{mL}$ of a $10^{-7} \mathrm{M}$ solution) on an electrode modified by 4-MeOBDS (-) and 4-MeBDS (------). $0.1 \mathrm{~V}$ $\mathrm{s}^{-1}$

Figure 2: Investigation of the analytical parameters A) Electric charge measured by LSSV analysis at different reduction potentials of a $10^{-6} \mathrm{M}$ solution of copper in $0.5 \mathrm{M} \mathrm{NaBF}_{4}$ with a reduction time of $3 \mathrm{~min}$ B) Electric charge measured by LSSV analysis of trapped copper ions, in optimal conditions, upon varying the reduction time C) Influence of the flow rates on the electric charge due to trapped copper, measured by LSSV analysis (the preconcentration step was performed with $250 \mathrm{~mL}$ of a $10^{-7} \mathrm{M}$ copper solution) D) Influence of the volume of copper solution $\left(10^{-7} \mathrm{M}\right)$ used for the preconcentration step on the electric charge of copper measured by LSSV analysis. Error bars are based on at least two reproducibility measurements. 
Figure 3 A) Calibration curve determined by LSSV analysis on the 4-MeOBDS-modified electrode as a function of $\mathrm{Cu}^{2+}$ concentration. B) Electric charge of trapped copper in the presence of interferents. Error bars are based on two or three reproducibility measurements.

Figure 1
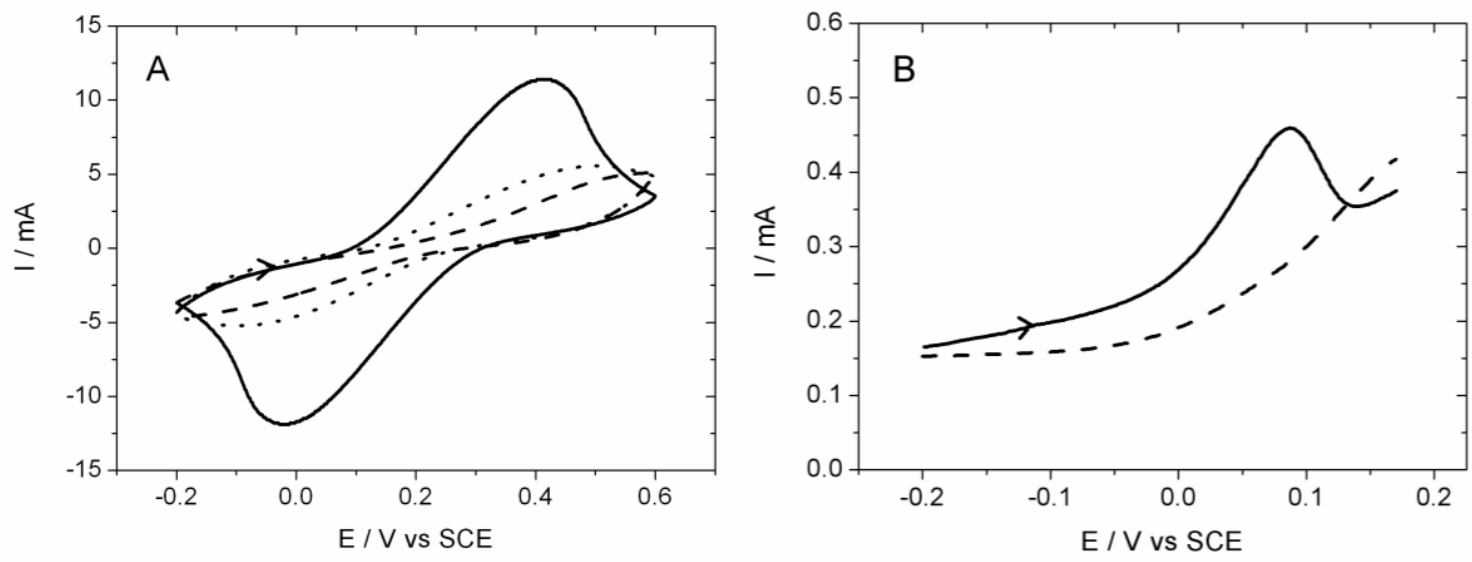
Figure 2
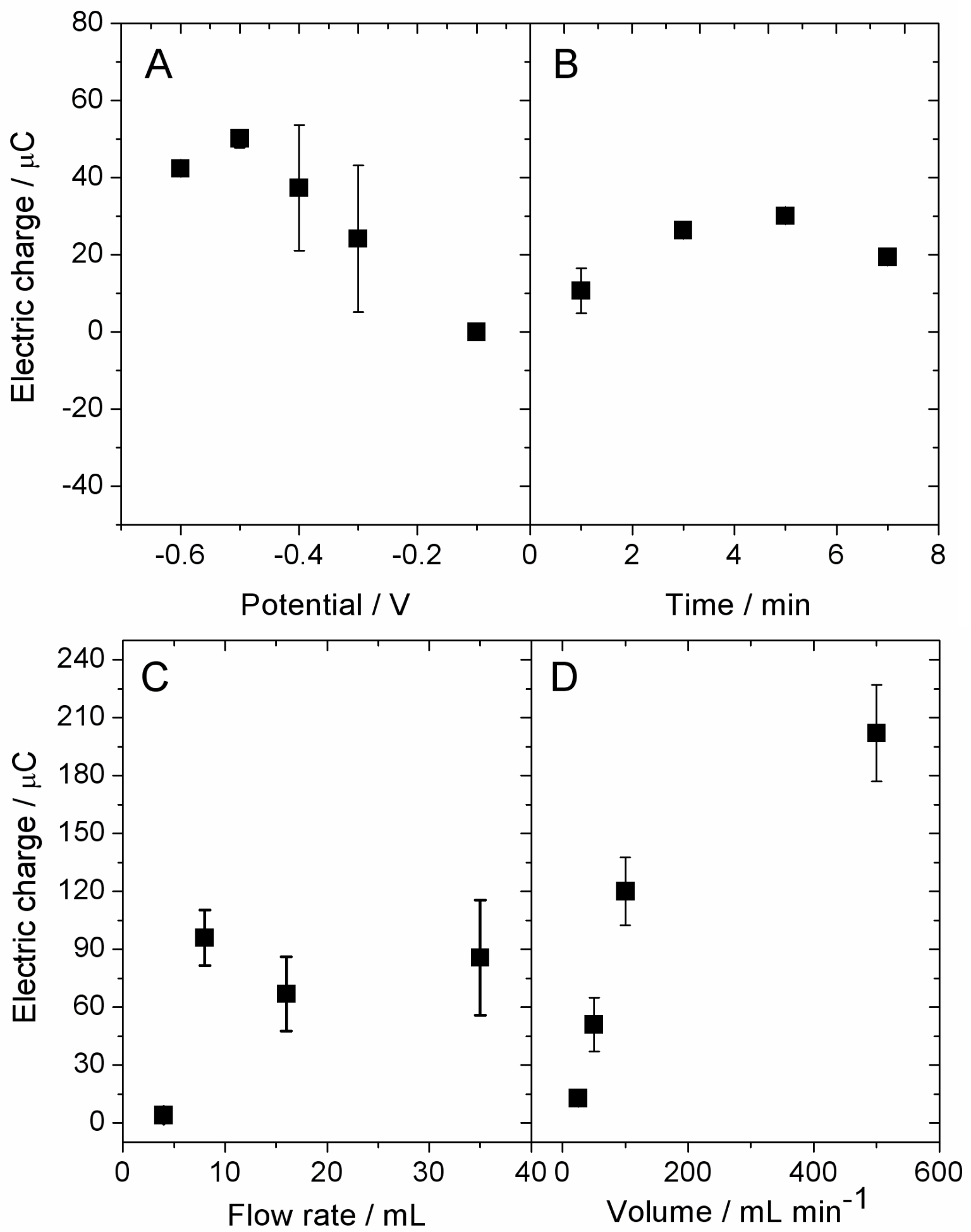
Figure 3

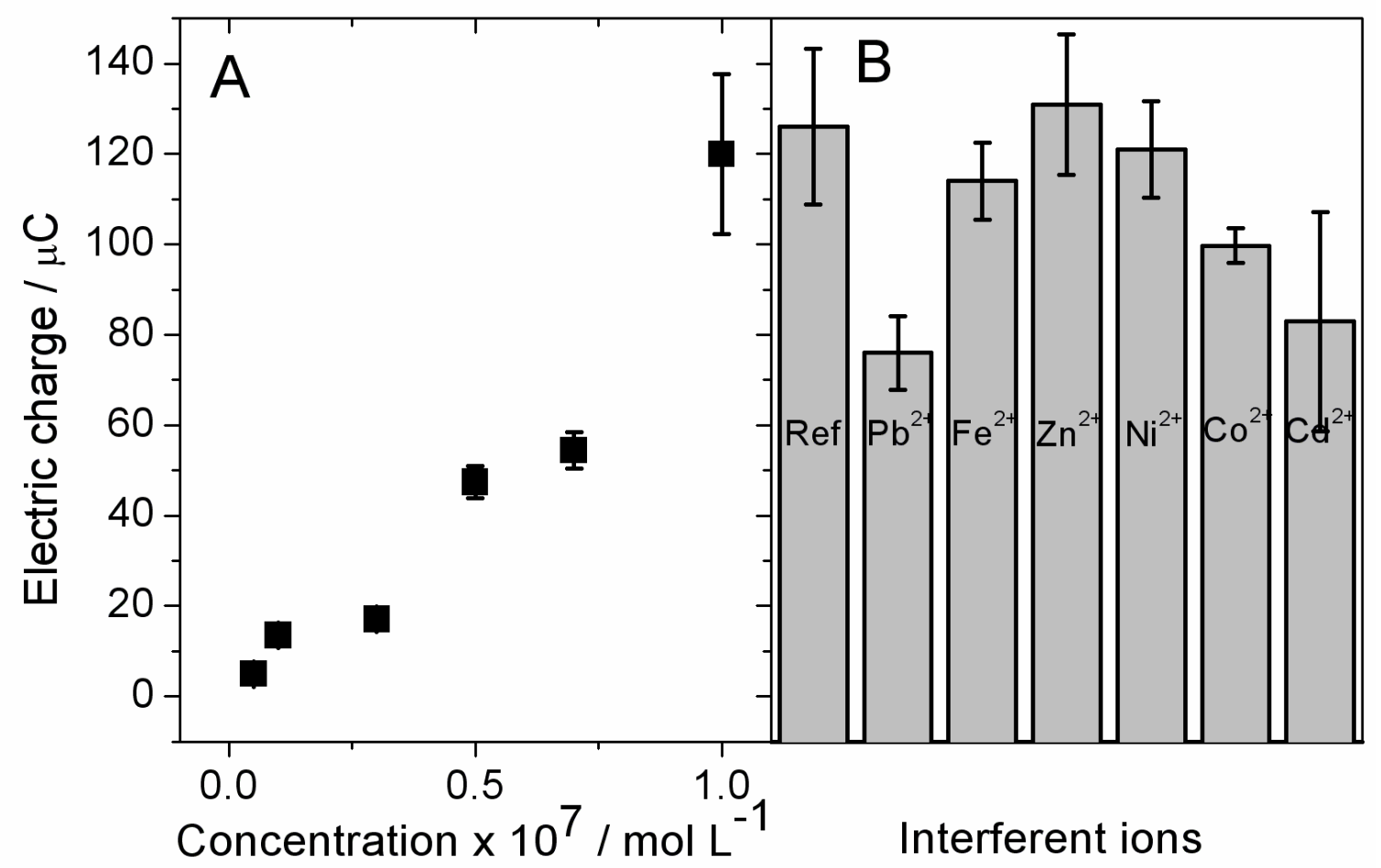

